\title{
Investigation of radiative effects of the optically thick dust layer over the Indian tropical region
}

\author{
S. K. Das ${ }^{1}$, J.-P. Chen ${ }^{1}$, M. Venkat Ratnam ${ }^{2}$, and A. Jayaraman ${ }^{2}$ \\ ${ }^{1}$ Department of Atmospheric Sciences, National Taiwan University, Taiwan \\ ${ }^{2}$ National Atmospheric Research Laboratory, Gadanki, Tirupati - 517 502, India
}

Correspondence to: S. K. Das (sanatkrdas@gmail.com)

Received: 20 August 2012 - Revised: 20 February 2013 - Accepted: 12 March 2013 - Published: 11 April 2013

\begin{abstract}
Optical and physical properties of aerosols derived from multi-satellite observations (MODIS-Aqua, OMI-Aura, MISR-Terra, CALIOP-CALIPSO) have been used to estimate radiative effects of the dust layer over southern India. The vertical distribution of aerosol radiative forcing and heating rates are calculated with $100 \mathrm{~m}$ resolution in the lower atmosphere, using temperature and relative humidity data from balloon-borne radiosonde observations. The present study investigates the optically thick dust layer of optical thickness $0.18 \pm 0.06$ at an altitude of $2.5 \pm 0.7 \mathrm{~km}$ over Gadanki, transported from the Thar Desert, producing radiative forcing and heating rate of $11.5 \pm 3.3 \mathrm{~W} \mathrm{~m}^{-2}$ and $0.6 \pm 0.26 \mathrm{~K} \mathrm{day}^{-1}$, respectively, with a forcing efficiency of $43 \mathrm{~W} \mathrm{~m}^{-2}$ and an effective heating rate of $4 \mathrm{~K} \mathrm{day}^{-1}$ per unit dust optical depth. Presence of the dust layer increases radiative forcing by $60 \%$ and heating rate by 60 times at that altitude compared to nondusty cloud-free days. Calculation shows that the radiative effects of the dust layer strongly depend on the boundary layer aerosol type and mass loading. An increase of $25 \%$ of heating by the dust layer is found over relatively cleaner regions than urban regions in southern India and further $15 \%$ of heating increases over the marine region. Such heating differences in free troposphere may have significant consequences in the atmospheric circulation and hydrological cycle over the tropical Indian region.
\end{abstract}

Keywords. Atmospheric composition and structure (Aerosols and particles) - Hydrology (Transport)

\section{Introduction}

Aerosols play an important role in regional and global climate change due to their potential in altering the radiation budget by scattering and absorbing the incoming solar and outgoing terrestrial radiation. Large variations in physical, optical, and chemical properties of these aerosols and their intense effects on the regional as well as global climate have made them a priority in recent times for the atmospheric research community. As per the present understanding, there is a high uncertainty in the overall radiative effects of aerosols on climate change (Bates et al., 2006). For example, globalaverage clear-sky aerosol direct radiative forcing is estimated to be about $-1.9 \mathrm{~W} \mathrm{~m}^{-2}$ at top of atmosphere (TOA) from the Moderate Resolution Imaging Spectroradiometer (MODIS) observed aerosol optical depth (AOD) with an uncertainty of $\pm 0.3 \mathrm{~W} \mathrm{~m}^{-2}$ (Bellouin et al., 2005). The uncertainties in the calculations are due to the anthropogenic aerosols. The average radiative forcing over ocean is reported in between -5.5 to $-6.7 \mathrm{~W} \mathrm{~m}^{-2}$ (Haywood, 1999; Boucher and Tanré, 2000; Chou et al., 2002; Christopher and Zhang, 2004; Yu et al., 2004), while the uncertainty is estimated to be about $-1.7 \mathrm{~W} \mathrm{~m}^{-2}$ (Christopher and Zhang, 2004). However, the uncertainty becomes higher in the presence of elevated aerosol layers of biomass burning and/or dust. From multisatellite observations, aerosol radiative forcing estimated at the surface is $-7.6 \mathrm{~W} \mathrm{~m}^{-2}$ over the Amazon with an uncertainty of $18 \%$ (Patadia et al., 2008). Presently, the estimation of aerosol heating rate is possible due to Cloud-Aerosol Lidar and Infrared Pathfinder Satellite Observation (CALIPSO), a space-borne lidar system launched in May 2006. CALIPSO provides vertically resolved aerosol extinction at two wavelengths and the depolarization ratio, which help to determine 
aerosol properties and aerosol height (Vaughan et al., 2009; Vernier et al., 2009). A comparative study on the retrieved vertical distribution of dust radiative heating rate over western Africa from aircraft lidar observations and CALIPSO revealed that the dust radiative heating rate derived from CALIPSO is in fair agreement with that derived from lidar observations (Lemaître et al., 2010). Recently, Gautam et al. (2011) estimated surface aerosol forcing using aerosol properties from combined observations of the AERONET and CALIPSO over the Indo-Gangetic Plain, which is known for high abundance of anthropogenic aerosols in India.

Dust is one of the major absorbing aerosols produced naturally by strong winds over arid regions. It is found to travel thousands of miles from the source regions, like from the Sahara to the Atlantic Ocean (Generoso et al., 2008) and the eastern Mediterranean (Kaskaoutis et al., 2008; Kosmopoulos et al., 2008), from the Gobi Desert to Taiwan (Nee et al., 2007; Wang et al., 2004) and further over the Pacific, etc. The absorbing feature of dust is characterized by the single scattering albedo (SSA), with low SSA representing high absorption and vice versa. Ground-based studies of the dust coming from the Sahara Desert reported that SSA is in the range $0.95-0.99$ at $0.55 \mu \mathrm{m}$, representing low absorption (Haywood et al., 2003). Earlier, Kaufman et al. (2001) also found a similar value (0.97) of SSA for the Saharan dust using satellite observations. However, SSA of dust can be reduced significantly, indicating high absorbing nature if mixed with other absorbing aerosols. SSA for dust particles mixed with aerosols coming from biomass burning is reported to be as low as 0.78 (Hess et al., 1998). A separate ground-based observation on the transported yellow dust from the Chinese desert to Japan reported that SSA of the dust is about 0.91 near the source and becomes as low as 0.80 after mixing with black carbon (BC) over urban region (Uchiyama et al., 2005). SSA for dust particles originating from the Thar Desert is reported to be around 0.95 near the source, but 0.90 when they are transported to central India, and in the process they are coated by BC aerosols (Chandra et al., 2004). It has been shown that SSA can be reduced to below 0.90 for the elevated dust-dominated layer over the Indo-Gangetic Plain, and further suggested that the associated enhanced solar absorption may amplify the regional climate warming (Gautam et al., 2010, 2009). In the past, Indian Ocean Experiment (INDOEX), ship cruise observations showed that a mixture of $\mathrm{BC}$ and dust aerosols, commonly known as atmospheric haze, have a lower SSA in the range $0.8-0.9$ and can produce larger forcing than the global mean value (Podgorny and Ramanathan, 2001; Krishnan and Ramanathan, 2002). Using unmanned aircraft observations, Ramanathan et al. (2007) estimated the rate of heating by these absorbing aerosols in the lower atmospheric layer $(0.5$ to $3 \mathrm{~km})$ and found the heating rate to be up to $0.7( \pm 0.3) \mathrm{K} \mathrm{day}^{-1}$. Another work on African desert dust revealed the radiative heating rate to be in between 1.5 to $4 \mathrm{~K} \mathrm{day}^{-1}$ (Lemaître et al., 2010). Such a high aerosol heating can significantly reduce rainfall and effectively spins down the hydrological cycle by decreasing the monsoon intensity (Ackerman et al., 2000; Ramanathan et al., 2001; Solmon et al., 2008).

In the present study we investigate the vertical distribution of radiative forcing and heating rate with a high resolution of $100 \mathrm{~m}$ due to a layer of transported dust (LTD) over Gadanki $\left(13.5^{\circ} \mathrm{N}, 79.2^{\circ} \mathrm{E}\right)$, a tropical station in southern India during May, the period just before the arrival of the Indian southwest monsoon. The dust originates in the Thar Desert during dust storms, particularly in the spring and the summer seasons (February-May), and strong winds transport the dust aerosols to other parts of the country, such as the Indo-Gangetic Plain and southern India (Dey et al., 2004; Badarinath et al., 2007, 2010). The current study identifies a layer of this transported dust over southern India using the space-borne lidar, Cloud-Aerosol Lidar with Orthogonal Polarization (CALIOP) onboard CALIPSO. The novelty of the present work is the use of vertical profiles of in situ temperature and relative humidity from balloon-borne GPS radiosonde measurements in the calculations of radiative effects to investigate the dust radiative forcing and heating rate. In the present study, profile of dust heating rate has been estimated with high vertical resolution $(100 \mathrm{~m})$ using a combination of multi-satellite retrieved aerosol optical and physical properties and measured profiles of meteorological parameters over an Indian tropical station.

\section{Database and analysis procedure}

\subsection{Optical and physical properties of aerosols from satellites}

Optical and physical properties of aerosols, such as AOD, the Ångstrom exponent, Aerosol Index (AI) and SSA are obtained from the MODIS onboard Aqua (Remer et al., 2002), the Ozone Monitoring Instrument (OMI) onboard Aura (Torres et al., 2007), and the Multi-angle Imaging SpectroRadiometer (MISR) onboard Terra (Diner et al., 2008). A list of instruments used in the present study with their resolutions and accuracies is given in Table 1, and a brief description about these space-borne sensors is given below.

MODIS provides a global image of retrieved aerosol parameters including AOD, the Angstrom exponent, and fine mode fraction. The MODIS sensor, onboard the polarorbiting NASA-EOS Aqua spacecraft crossing over the equator at 13:30 local solar time (Levy et al., 2007), continuously scans the globe in 36 channels in the spectral range from 0.41 to $14.4 \mu \mathrm{m}$, with three spatial resolutions, viz. $250 \mathrm{~m}$ ( 2 channels), $500 \mathrm{~m}$ (5 channels) and $1 \mathrm{~km}$ (29 channels). Aerosol parameters from MODIS observations are retrieved over land and oceanic surfaces using separate algorithms and eight of these channels (0.47-2.13 $\mu \mathrm{m})$ (Kaufman et al., 1997; Hsu et al., 2004; Remer et al., 2005). In the present study, AOD and Ångstrom exponent with $1^{\circ} \times 1^{\circ}$ 
Table 1. Details of the instruments used in the present study.

\begin{tabular}{lcccc}
\hline Parameter & Instrument & Onboard & Resolution & Accuracy \\
\hline Aerosol optical depth & MODIS & AQUA & $1^{\circ} \times 1^{\circ}$ & $\pm 0.05 \pm 0.15 \times \mathrm{AOD}^{\mathrm{a}}$ \\
$\begin{array}{l}\text { Aerosol index } \\
\text { Extinction coefficients, }\end{array}$ & OMI & AURA & $0.25^{\circ} \times 0.25^{\circ}$ & - \\
$\begin{array}{l}\text { Depolarization ratio, } \\
\text { Angstrom exponent }\end{array}$ & CALIOP & CALIPSO & $\begin{array}{c}30 \mathrm{~m}(\mathrm{ver}) \\
\&\end{array}$ & - \\
$\begin{array}{l}\text { Single-scattering albedo } \\
\text { Meteorological parameters }\end{array}$ & MISR & TERRA & $17.6 \mathrm{~km} \times 17.6 \mathrm{~km}$ & $\pm 0.02^{\mathrm{b}}$ \\
& Radiosonde & Balloon & $10 \mathrm{~m}$ & $0.5 \mathrm{~m} \mathrm{~s}^{-1}, 0.5^{\circ} \mathrm{C}, 5 \%^{\mathrm{c}}$ \\
\hline a Remer et al. (2002); ${ }^{\mathrm{b}}$ Kalashnikova and Kahn (2006); ${ }^{\mathrm{c}}$ Nath et al. (2009) & &
\end{tabular}

grid resolution are obtained from level 3 data corresponding to collection 5 (C005) over southern India.

OMI onboard the Finnish-Dutch AURA satellite, crossing the equator at 13:38 local solar time, provides UV AI data retrieved from the upwelling radiance at TOA in the ultraviolet and visible $(0.270-0.500 \mu \mathrm{m})$ regions of the solar spectrum. The OMI near-UV aerosol algorithm uses the measurements made at two wavelengths $(0.354$ and $0.388 \mu \mathrm{m})$ in the UV region to take advantage of the large sensitivity of the upwelling radiances to aerosol absorption in this spectral range (Torres et al., 1998, 2007). Thus, the hot spot regions of AI represent the source regions of UV absorbing aerosols like desert dust or biomass burning aerosols (Torres et al., 1998; Eck et al., 2001; Torres et al., 2007). Over arid and semi-arid regions, AI represents proportional amount of dust aerosols (Torres et al., 2007) and used to identify the source and the spatial extent of dust storm events (Kaskaoutis et al., 2008; Badarinath et al., 2010; Das et al., 2011, etc). The combination of MODIS and OMI observations can be effectively used to identify the presence of dust loading (Kaskaoutis et al., 2008). In the present study the OMI-AI Level 3 globalgridded product $\left(0.25^{\circ} \times 0.25^{\circ}\right.$ spatial resolution $)$ along with MODIS-derived AOD is used to detect the dust aerosols over the source region, the Thar Desert, and transported dust plume over the downwind region, southern India.

MISR onboard the NASA-EOS Terra spacecraft, which is in a sun-synchronous orbit and crosses the equator at 10:30 local solar time, provides aerosol optical and physical properties. It is a push broom imaging instrument operating at four spectral bands centered at $0.446,0.558,0.672$, and $0.867 \mu \mathrm{m}$ in each of its nine separate cameras oriented along the orbital track with surface viewing zenith angles in the range $\pm 70.5^{\circ}$ (Diner et al., 2008). It covers an about $400 \mathrm{~km}$ swath, providing a global image of aerosol properties. MISR Aerosol retrievals can provide aerosol products at $17.6 \mathrm{~km} \times 17.6 \mathrm{~km}$ spatial resolution (Martonchik et al., 2002). In the present study, SSA is obtained from the MISR Level 2 product with a spatial resolution of $0.5^{\circ} \times 0.5^{\circ}$. Earlier studies show that SSA obtained from MISR has a good correlation with ground-based observations (Kalashnikova and Kahn, 2006; Chen et al., 2008; Kahn et al., 2010) and is also used to esti- mate aerosol radiative forcing over land (Chen et al., 2009), which provides enough confidence to use SSA-MISR in the present study for the calculation of dust radiative effects. Dominance of non-spherical dust particles can underestimate SSA. Including non-spherical particles in MISR aerosol retrieval algorithm helps to retrieve SSA with more accuracy during the dust events. MISR-SSA is found to be in good agreement $( \pm 0.02)$ with SSA derived from AERONET observations (Kalashnikova and Kahn, 2006).

Vertical information of aerosol extinction coefficients and depolarization ratio are obtained from CALIOP onboard CALIPSO (Hu et al., 2007; Vaughan et al., 2009). CALIPSO passes over the equator at 13:31 local solar time, one minute behind Aqua. The space-borne lidar, CALIOP, observes aerosol loading at $0.532 \mu \mathrm{m}$ vertically as well as horizontally with high spatial resolution along the satellite track. From the surface to $8 \mathrm{~km}$, the vertical resolution is $30 \mathrm{~m}$ and the nominal horizontal resolution is $1 / 3 \mathrm{~km}$. CALIOP measures the total backscattered signal at two wavelengths $(0.532$ and $1.064 \mu \mathrm{m})$, and perpendicularly polarized backscattered signal at $0.532 \mu \mathrm{m}$. The backscattered signals are converted to an extinction profile using the algorithm described in Vaughan et al. (2009). CALIPSO also provides the profile of depolarization ratio retrieved from perpendicularly polarized back scattered signals at $0.532 \mu \mathrm{m}$ (Vaughan et al., 2005). Depolarization ratio is a good parameter to identify the elevated dust aerosol. Earlier studies identified the dust layer having depolarization ratio greater than 0.2 (Nee et al., 2007; Omar et al., 2009; Guan et al., 2010). The vertical distribution of the Ångstrom exponent is calculated using the extinction values at the two wavelengths, and this parameter can give the information about the vertical distribution of aerosol size. CALIPSO level 2 Vertical Feature Mask (VFM) products provide vertical mapping of the locations of aerosols and clouds together with information about the types of each layer, and the discrimination between aerosols and clouds is expected to be good in these products (Vernier et al., 2009; Badarinath et al., 2010; Niranjan et al., 2012).

The quasi-simultaneity of the combined observations of the Aqua, CALIPSO and Aura satellites flying within eight minutes on the A-train platform makes it possible to 
Table 2. Physical and optical properties of the dust layer observed over Gadanki, and its radiative forcing and heating rate in the atmosphere.

\begin{tabular}{ccccccc}
\hline Date & $\begin{array}{c}\text { Dust layer } \\
\text { height } \\
(\mathrm{km})\end{array}$ & $\begin{array}{c}\text { Dust layer } \\
\text { thickness } \\
(\mathrm{km})\end{array}$ & $\begin{array}{c}\text { Dust layer } \\
\text { optical thickness }\end{array}$ & $\begin{array}{c}\text { Depolarization } \\
\text { ratio }\end{array}$ & $\begin{array}{c}\text { Radiative } \\
\text { forcing } \\
\left(\mathrm{W} \mathrm{m}^{-2}\right)\end{array}$ & $\begin{array}{c}\text { Heating } \\
\text { rate } \\
\left(\mathrm{K} \mathrm{day}^{-1}\right)\end{array}$ \\
\hline 2 May 2007 & 2.0 & 3.8 & 0.22 & 0.26 & 12 & 0.7 \\
4 May 2007 & 1.8 & 1.4 & 0.10 & 0.21 & 9 & 0.2 \\
9 May 2007 & 2.0 & 3.4 & 0.14 & 0.20 & 10 & 0.4 \\
11 May 2007 & 4.0 & 4.1 & 0.31 & 0.50 & 18 & 1.0 \\
14 May 2007 & 2.5 & 2.0 & 0.16 & 0.32 & 10 & 0.7 \\
16 May 2007 & 2.8 & 1.4 & 0.14 & 0.34 & 11 & 0.4 \\
18 May 2007 & 3.0 & 4.5 & 0.12 & 0.23 & 8 & 0.3 \\
20 May 2007 & 2.5 & 3.5 & 0.19 & 0.25 & 14 & 0.8 \\
23 May 2007 & 2.2 & 2.8 & 0.25 & 0.30 & 15 & 0.8 \\
27 May 2007 & 1.8 & 2.2 & 0.15 & 0.20 & 8 & 0.7 \\
\hline Average & $2.5 \pm 0.7$ & $2.9 \pm 1.1$ & $0.18 \pm 0.06$ & $0.28 \pm 0.09$ & $11.5 \pm 3.3$ & $0.60 \pm 0.26$ \\
\hline
\end{tabular}

investigate an aerosol system with full closure. In the present study, dust aerosols transported from the Thar Desert to southern India are investigated using the MODIS-Aqua and OMI-Aura observations. The dust layer at higher altitude (2$6 \mathrm{~km}$ ) is identified over southern India from the vertical distribution of depolarization ratio, with values greater than 0.2 and corresponding to a relatively high extinction coefficient and a low Ångstrom exponent. Though all these data are available globally, we have focused our analysis on a grid point centered over Gadanki since over this location various collocated and routine in situ observations of meteorological parameters using balloon-borne radiosondes are available. In addition, Gadanki is a remote rural place about $30 \mathrm{~km}$ to the east of the temple city, Tirupati $\left(13.65^{\circ} \mathrm{N}, 79.42^{\circ} \mathrm{E}\right)$, which makes this region relatively clean. The identification of the dust layer over cleaner regions is easier as the boundary layer aerosols are less absorbing. Although dust storms occurring over the Thar Desert in western India are quite common, particularly during February to May, we restrict our analysis to the month of May as huge amount of biomass burning in the agricultural fields takes place in the surrounding areas of Gadanki during March and April, which may obscure dust signals. Careful inspection of multi-satellite observations shows optically thick dust layers over Gadanki during ten days in May 2007 (listed in Table 2).

\subsection{Meteorological parameters}

The radiative effects of the dust layer are calculated using the meteorological parameters at Gadanki from the in situ measurements. Meteorological parameters are analyzed over the Indian subcontinent using European Centre for Medium-Range Weather Forecasts (ECMWF) data. In the present study, daily measured profiles of high-resolution GPS radiosonde meteorological data over Gadanki are also included. These meteorological parameters are measured regularly over Gadanki every day usually at 12:00 UT
$(\mathrm{LT}=\mathrm{UT}+05: 30 \mathrm{~h})$. The vertical resolution of these parameters is $10 \mathrm{~m}$, and the measured horizontal wind, temperature and relative humidity $(\mathrm{RH})$ are measured with an accuracy of $0.5 \mathrm{~m} \mathrm{~s}^{-1}, 0.5^{\circ} \mathrm{C}$ and $5 \%$, respectively. More details about the instrument and the accuracy of the measurements are described by Nath et al. (2009).

Spatial distribution of wind pattern, temperature and $\mathrm{RH}$ at $800 \mathrm{mb}$ pressure level obtained from ECMWF data and profiles of wind speed and direction, temperature and $\mathrm{RH}$ during three typical dusty days are shown in Fig. 1. Meteorological parameters at 12:00 UT during 14, 16 and 18 May 2007 are shown in Fig. 1 panels $(a, b, c),(d, e, f)$ and $(g, h, i)$, respectively. In Fig. 1a, d, g, shaded colors represent spatial distribution of $\mathrm{RH}$, arrows are for wind direction and speed, and line contours show the temperature distribution at $800 \mathrm{mb}$ pressure level (about $2.2 \mathrm{~km}$ altitude). This altitude is found to be the place of existence of the optically thick transported dust layer over southern India (discussed in Sect. 3.2). The star represents the location of Gadanki, where daily radiosonde measurements are carried out. In Fig. 1a, d, $\mathrm{g}$, a very low RH of less than $20 \%$ with high temperature of more than $22^{\circ} \mathrm{C}$ is found over the Thar Desert during all the dusty days. A narrow region of low RH with high temperature $\left(>18^{\circ} \mathrm{C}\right)$ is also clearly observed connected from this hot dry arid region to the east coast region of southern India. This region also experiences strong wind coming from arid regions. However, wind on 16 May 2007 becomes weaker than that on 14 and 18 May 2007. Interestingly, Gadanki is located within this narrow region. Therefore, it is clearly noticed from ECMWF data that hot dry air comes from the Thar Desert to Gadanki during these dusty days, which favor the transport of dust from the Thar Desert.

Figure 1, panels $(b, c),(e, f)$ and $(h, i)$ show the wind, $\mathrm{RH}$ and temperature profiles obtained from radiosonde measurements at Gadanki on 14, 16 and 18 May 2007, respectively. In Fig. 1b, e, f the dashed lines represent the wind 

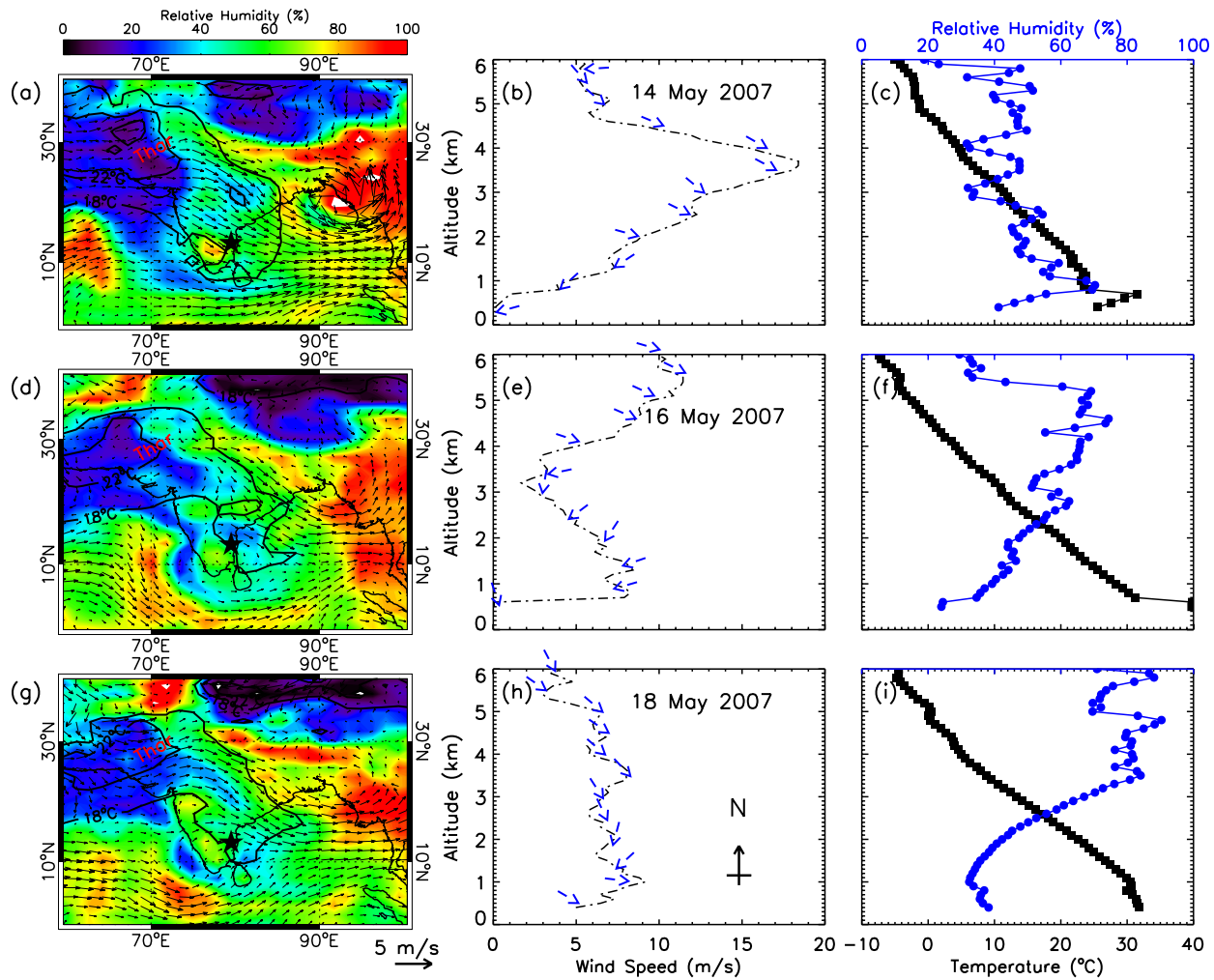

Fig. 1. Meteorological parameters observed on the three typical dusty days - 14, 16, and 18 May 2007 in panels (a), (b), and (c), (d), (e), and (f), and (g), (h), (i), respectively. The spatial distribution of wind, temperature and relative humidity (RH) at $800 \mathrm{mb}$ pressure level are shown at 12:00 UT in (a), (d), (g). Arrows represent wind pattern, the shaded colors and contour lines are for spatial distribution of RH and temperature, respectively. "Thar" shows the arid region of the Thar Desert and the star represents the location of Gadanki, where radiosonde measurements are carried out. (b), (c), (d), (f) and (h), (i) show the profiles of wind parameters, temperature (black boxes), and RH (blue circles) obtained from radiosonde measurements on 14, 16, and 18 May 2007. In (b), (e), (h), dashed lines show wind speed and arrows indicate wind direction. The upward-pointing arrow indicates north and the one 90 degrees clockwise shows east.

speed and arrows indicate the wind direction. The upwardpointing arrow indicates north and the one 90 degrees clockwise shows east. A westerly wind is observed throughout the observation period. However, there is a strong variation in wind speed with altitude. On 14 May 2007, wind speed increased from surface to $3 \mathrm{~km}$, while on 16 May 2007, wind speed decreased for the first $3 \mathrm{~km}$ and thereafter increased for the next $3 \mathrm{~km}$. However, on 18 May 2007, wind speed was $8 \mathrm{~m} \mathrm{~s}^{-1}$ above $1 \mathrm{~km}$ and remained nearly the same up to $5 \mathrm{~km}$. The temperature and $\mathrm{RH}$ profiles also show significant day to day variation in the Fig. $1 \mathrm{c}, \mathrm{f}$, i. The surface temperature is observed to be below $30^{\circ} \mathrm{C}$ on 14 May 2007 and higher than $30^{\circ} \mathrm{C}$ on 16 and 18 May 2007. The average temperature within the atmosphere below $3 \mathrm{~km}$ is observed to be warmer by $2-4^{\circ} \mathrm{C}$ on 16 and 18 May 2007 . The RH profiles also show interesting features. On 14 May 2007, RH is almost constant at about $50 \%$ within $6 \mathrm{~km}$ above ground. However, on 16 and 18 May 2007, RH is lower than 50\% below $3 \mathrm{~km}$ and about $80 \%$ above $3 \mathrm{~km}$. These observations show that on 16 and 18 May 2007, the atmosphere within
$3 \mathrm{~km}$ from the surface was drier and warmer, which provides suitable conditions for sustenance of the dust layer.

\section{Observation results}

\subsection{Identification of source region}

AI is a good parameter to identify the source of dust, mainly over continental regions, because it is a quantitative representation of absorption of aerosols in the UV region (Torres et al., 2007). Though biomass burning aerosols also have large absorption in the UV region, the confidence regarding the existence of dust in the arid atmosphere is significantly higher. Therefore, the hot spot regions of AI over arid regions are considered as a source of dust (Generoso et al., 2008; Kaskaoutis et al., 2008) and the progress of the hot spot region with consistently high AOD obtained from successive satellite images provides information about the progress of the transported dust over downwind regions.

In this paper the spatial distribution of $\mathrm{AI}$ and AOD during the dusty days - 14, 16 and 18 May 2007 - are shown in the 

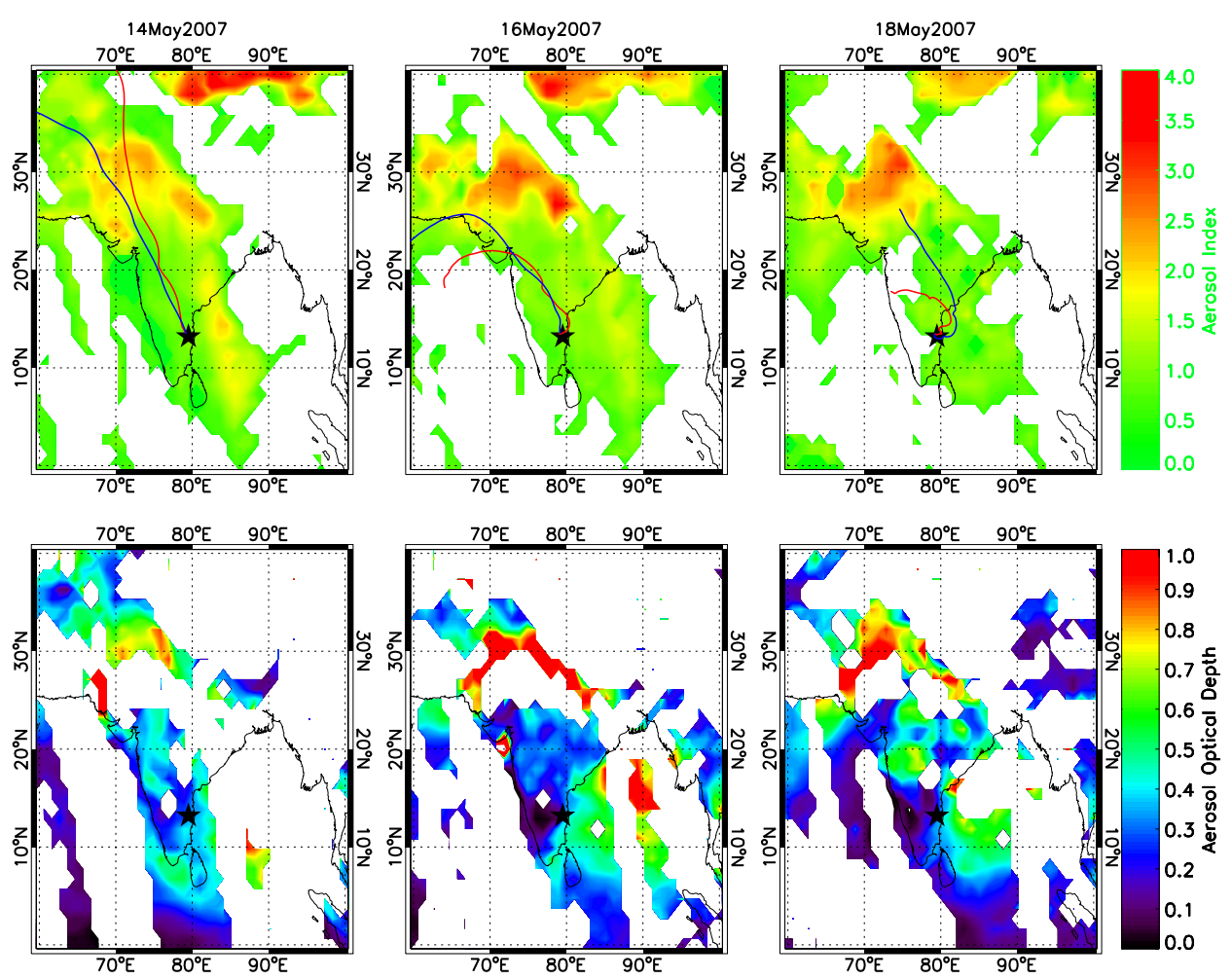

Fig. 2. Spatial distribution of OMI-AI (top) and MODIS-AOD (bottom) observed on 14, 16, and 18 May 2007. The solid lines in the top row show the five days air back trajectories at initial heights of $4 \mathrm{~km}$ (red) and $5 \mathrm{~km}$ (blue). The star denotes the location of Gadanki. The white patches over southern India and oceanic region in MODIS images are due to the presence of clouds.

top and bottom rows of Fig. 2, respectively. On all the three days, a hot spot region in AI is found over the Thar Desert, which is the source of dust aerosols. On 14 and 16 May 2007, a high $\mathrm{AI}$ value of 2.5 is connecting this hot spot region to the Bay of Bengal $(\mathrm{BoB})$ via a narrow region through central India. This narrow high AI region is situated very near to the observational site, Gadanki, marked by a star in the figure. On 18 May 2007 the narrow region of high AI connecting the Thar Desert and BoB is less prominent. Similarly, on these three days, AOD is also high (around 1) over the Thar Desert and is following a similar pattern of spatial distribution, as can be seen in the figure. AOD over Gadanki is also found to be at a level of about $0.3,0.28$ and 0.24 on 14,16 and 18 May 2007, respectively. This high AOD over Gadanki is due to a layer of dust aerosols present at an altitude of $2.5 \mathrm{~km}$ and thickness of $1.5 \mathrm{~km}$ (discussed in the next section).

For further confirmation of identification of source of the dust over Gadanki, five days air back trajectories are computed using Hybrid Single-Particle Lagrangian Integrated Trajectory (HYSPLIT) model (Draxler and Hess, 1998) with initial height of $4 \mathrm{~km}$ (red) and $5 \mathrm{~km}$ (blue) altitude, and are shown in the top panels. These back trajectories are indicating the Thar Desert as the source of dust over Gadanki. More interestingly, the path of the back trajectories also matches with regions of high $\mathrm{AI}$ and high AOD starting from the Thar
Desert to $\mathrm{BoB}$. This is a clear indication of the transportation of dust from the Thar Desert to BoB via southern India.

\subsection{Vertical distribution of aerosol properties}

Vertical distribution of aerosol extinction coefficient at 0.532 and $1.064 \mu \mathrm{m}$ and depolarization ratio at $0.532 \mu \mathrm{m}$ are obtained from CALIPSO level 2 data. Vertical distribution of Ångstrom exponent is calculated from extinction coefficients at these two wavelengths. The value of extinction coefficient depends on the total aerosol loading, whereas depolarization ratio and Ångstrom exponent values depend on the irregularities in particle shape and size, respectively. Depolarization ratio will be high for a particle of irregular shape such as dust, and close to zero for spherical particles like liquid cloud droplets (Murayama et al., 1999, 2001; Hu et al., 2009; Omar et al., 2009; Guan et al., 2010). Earlier ground-based and aircraft experiments reported that the depolarization ratio is as high as 0.97 for freshly generated dust particles and can decrease to 0.2 for aged dust particles externally mixed with pollutant (Murayama et al., 2001; Gobbi et al., 2004; Nee et al., 2007; de Villiers et al., 2010). The dust over the Thar Desert is highly irregular in shape as seen in scanning electron microscope (SEM) images (Mishra and Tripathi, 2008) and found to have a depolarization ratio as high as 1.0 in CALIPSO observations. Following the earlier works, we thus 

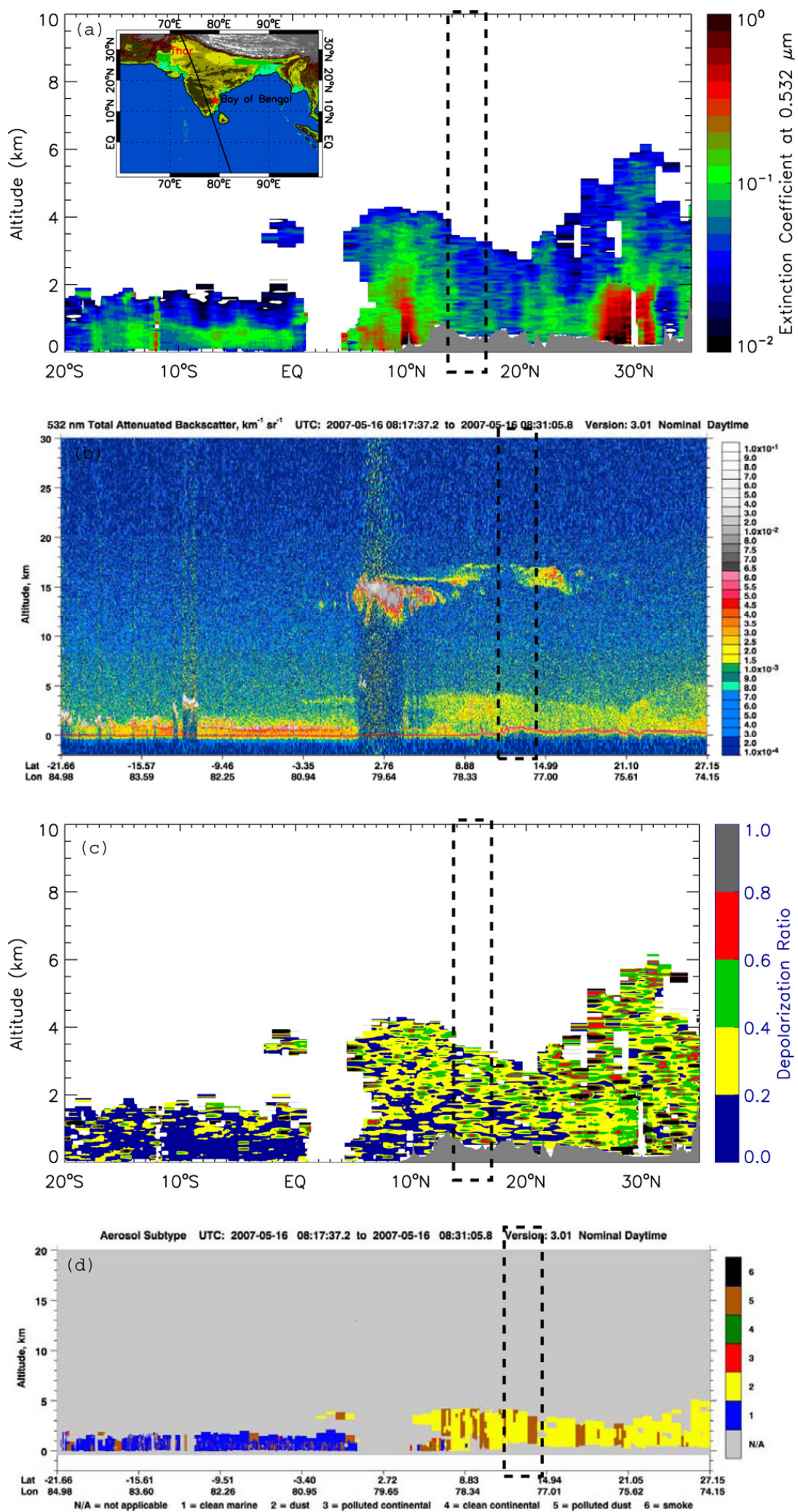

Fig. 3. Vertical distribution of (a) aerosol extinction coefficient at $0.532 \mu \mathrm{m}$, (b) total backscattered signal, (c) depolarization ratio, and (d) aerosol type assessment along the overpass trajectory are shown on 16 May 2007. The topography of the Indian Peninsula is shown in the inset and the solid line represents the CALIPSO overpass trajectory. The star shows the location of Gadanki. The dashed rectangular boxes represent the area of interest with the center closest to Gadanki. 

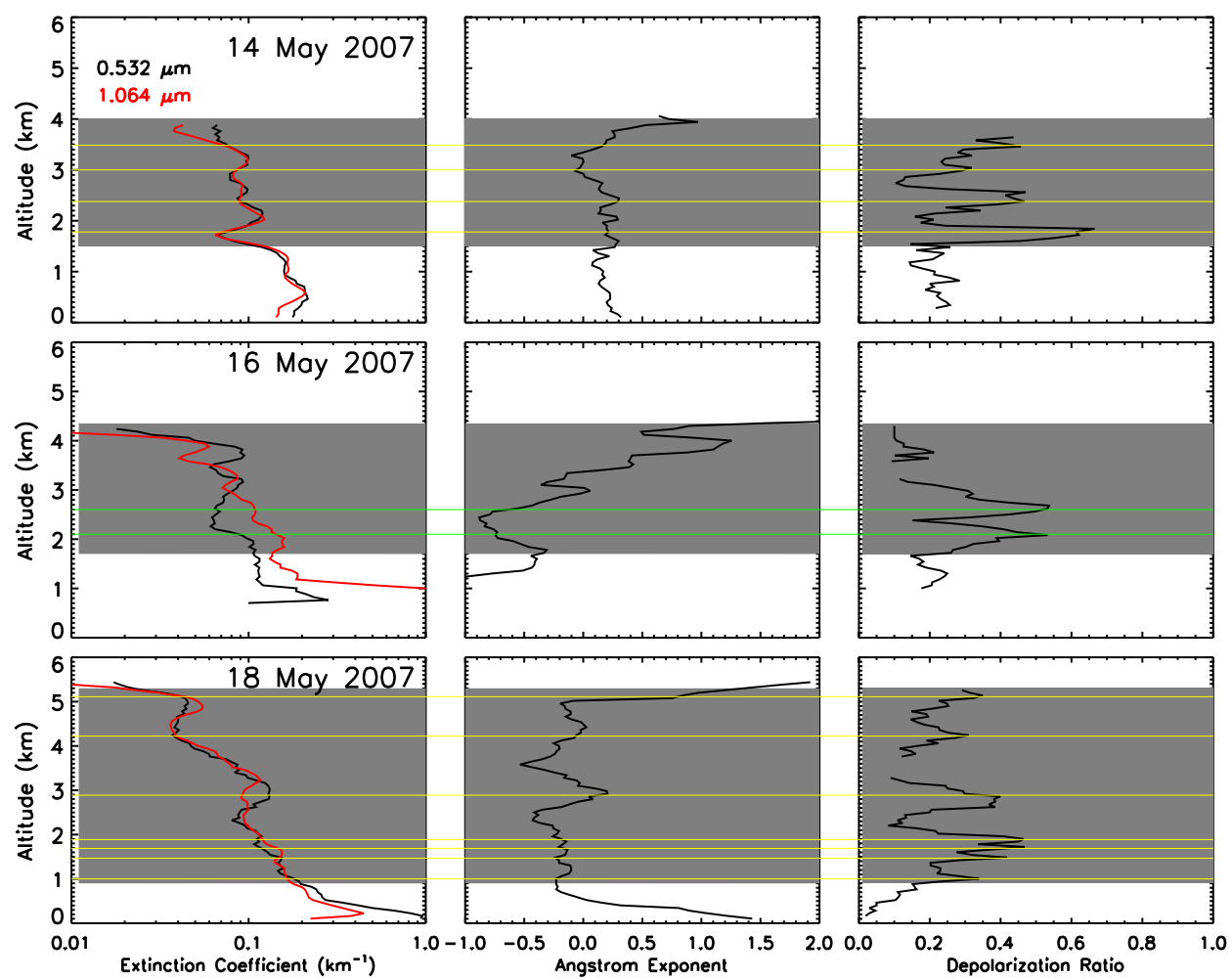

Fig. 4. Profiles of aerosol extinction coefficient, Ångstrom exponent and depolarization ratio obtained from CALIPSO on 14, 16 and 18 May 2007 over Gadanki. Shaded regions represent the optically thick dust layers. The horizontal lines show the peak of depolarization ratio indicating the fine layers of embedded pollutant aerosols (yellow lines) on 14 and 18 May, and layers of concentrated dust (green lines) on 16 May. See text for more details.

set a threshold depolarization ratio value of 0.2 for the layer of aerosols to be considered as a dust layer.

Typical vertical distribution of aerosol optical properties obtained from CALIPSO observations passing over the Thar Desert and near Gadanki on 16 May 2007 are shown in Fig. 3. Aerosol extinction coefficient at $0.532 \mu \mathrm{m}$, total backscattered signal retrieved by CALIOP, depolarization ratio and aerosol type assessment are in the four panels, respectively. The inset in Fig. 3a shows topography of the Indian Peninsula and the solid line represents the trajectory of the CALIPSO overpass. The location of the Thar Desert is highlighted and the radiosonde measurement station, Gadanki, is also marked by a star. The dashed rectangular box in all the panels represents the study area, keeping Gadanki at its center. In Fig. 3a, a high extinction coefficient of about 1.0 is found over the Thar Desert and southern India (near the $10^{\circ} \mathrm{N}$ region). The region of interest is located in between these two high values. A continuous high backscattered signal found from the Thar Desert to the study area in Fig. 3b indicates the transport of dust from the Thar Desert. The vertical distribution of depolarization ratio in Fig. 3c shows a high value of about 0.8 over the Thar Desert, indicating dominance of irregular dust particles, lifted up to $6 \mathrm{~km}$. This high value continues up to the marine region, while lati- tudinally, near the surface over southern India, a very low value $(>0.2)$ of depolarization ratio is observed, indicating dominance of relatively spherical aerosols. These spherical aerosols also have a high extinction coefficient, showing high absorption properties that mainly differ from the scattering irregular dust particles. The depolarization ratio is also very low over the marine region, indicating spherical aerosol, but their extinction coefficient is relatively lower, indicating scattering properties. These spherical aerosols over marine region are mainly sea salt aerosols. Figure $3 \mathrm{~d}$ represents the aerosols type assessment for that day, defined on the basis of CALIPSO observations, as reported in the literature (Omar et al., 2009; Yorks et al., 2009). Figure 3d shows that dust particles (yellow in color) are present from the Thar Desert to southern India, but are mixed with pollutants (brown in color) over some regions in southern India. We have seen from back trajectory analysis that dust over southern India is transported from the Thar Desert. During the travel period, dust mixes with pollutants. Over the region of interest both the dust and mixed dust are noticed. However, the depolarization ratio indicates the irregular dust in the higher altitudes with fine embedded layers of spherical pollutants. A more detailed investigation of the vertical distribution of aerosol 
properties is required to identify the fine layers of pollutants in the thick dust layer and will be taken up at a later stage.

Profiles of the extinction coefficients, the Ångstrom exponent and depolarization ratio on the three days chosen for investigation are shown in Fig. 4. Profiles over Gadanki presented in Fig. 4 are the averaged profiles obtained from CALIPSO within $\pm 0.5^{\circ}$ of the nearest location of Gadanki along the satellite track. Distinct dust layers can be seen on 14, 16 and 18 May 2007 between 1.5 and $4 \mathrm{~km}$, as highlighted by the grey shading. The three aerosol parameters extinction coefficients, Ångstrom exponent and depolarization ratio - are not uniform within the dust layer and, especially, the depolarization ratio shows alternating maxima (or peaks) and minima. Such a sublayered structure is not merely the result of vertical variation in dust concentration. Each peak may represent a layer with additional aerosols of different types, depending on the extinction coefficient and depolarization ratio. For example, on 14 May, there are three local peaks in the depolarization ratio that are associated with minima in the extinction coefficient (at $1.064 \mu \mathrm{m}$ ), and vice versa. For a fixed size (and shape) distribution of dust, a change in dust concentration affects the extinction coefficient, but no other parameters. Therefore, the coherent variations shown in Fig. 4a cannot be explained solely by the differences in dust concentration. One likely cause is the presence of other aerosols. When dust is mixed externally with hygroscopic aerosol particles, which are generally smaller and spherical, the mean depolarization ratio decreases, whereas the Ångstrom exponent increases. For purely internal mixing (i.e., all hygroscopic material coated on dust), dust particles will become larger and more spherical, especially when the hygroscopic materials deliquesce under high humidity, which also leads to a larger extinction coefficient (due to enhanced scattering and absorption) and smaller depolarization ratio. Such a relationship seems to fit the behavior seen on 14 May. It is found to be same on 18 May also, but with even finer structures, especially the coherent changes in Ångstrom exponent and depolarization ratio. This observation suggests that the optically thick dust layer at high altitudes over tropical India is not only purely irregular dust layers transported from the Thar Desert, but also embedded with thin layers of pollutant aerosols. This is possible during transport of the dust plume over polluted regions. Earlier studies reported a significantly large number of biomass burning during this period over central India loading biomass burning aerosols into the atmosphere (Kharol and Badarinath, 2006; Badarinath et al., 2008). The situation is different on 16 May, showing two prominent peaks in the depolarization ratio that are associated with local maxima in extinction coefficient (marked by the green horizontal lines). This indicates a vertical variation in mineral dust concentration, but no signature of embedded pollutant aerosols. The backward trajectories analysis in Fig. 2 suggests that air parcels on 14 and 18 May travel mostly over land, so it is possible that anthropogenic pollutants at the upwind areas have enough time to enter the free troposphere in stratified fine layers. On the other hand, air parcels in the 16 May case originated from the Arabian Sea, so their short duration over land did not permit significant entraining of the boundary layer pollutants into the dust layer aloft.

In general, the extinction coefficient at $0.532 \mu \mathrm{m}$ in the dust layer is around $0.1 \mathrm{~km}^{-1}$. The Ångstrom exponent in the dust layer is close to zero and in some cases negative. At the center of the dust layers, depolarization ratios are high and close to 0.5 , but much less than the value of 1.0 over the Thar Desert. The height, thickness, extinction coefficient, depolarization ratio, optical thickness and Ångstrom exponent of the dust layers retrieved from CALIPSO and MODIS on all ten days of interest are given in Table 2. The average height of the dust layers is $2.5 \pm 0.7 \mathrm{~km}$, the average depolarization ratio within the dust layers is $0.28 \pm 0.09$ and the average optical thickness of the dust layer is $1.8 \pm 0.06$.

\section{Radiative heating}

\subsection{Implications of aerosol radiative forcing and heat- ing rate}

AOD, Ångstrom exponent, SSA and vertical distribution of aerosol extinction coefficient obtained from a set of multiple satellites are incorporated into the Santa Barbara DISORT Atmospheric Radiative Transfer (SBDART) model to compute the vertical distribution of aerosol radiative forcing during clear-sky conditions. SBDART, a well recognized radiative transfer model in the atmospheric research community, was developed by the scientists at the University of California, Santa Barbara (Ricchiazzi et al., 1998). This model includes all the important processes that affect the ultraviolet, visible and infrared radiation fields. SBDART provides the radiation fluxes at each layer of the atmosphere. In the present study, radiation fluxes are calculated under withaerosol and without-aerosol conditions in the shortwave region $(0.25-4.0 \mu \mathrm{m})$. The daily aerosol radiative forcing is estimated by taking the differences in radiation fluxes of withaerosol and without-aerosol condition at each layer of the atmosphere, running the radiative transfer model for one hour interval. The atmosphere is defined by using the profile of atmospheric temperature and RH observed by radiosondes. The columnar ozone concentration is obtained from OMIAura. The atmosphere is divided into 65 horizontal layers with thickness around $0.1 \mathrm{~km}$ in the lower atmosphere. It is to be noted that defining fine layers in lower atmosphere is only possible with the radiosonde measurements and CALIPSO observations, which is the uniqueness of this study. Radiative forcing is highly sensitive to land surface reflectance. The surface reflectance is obtained from nadir MODIS-Aqua 16-day level 3 albedo product with a spatial resolution of $1 \mathrm{~km}$. MODIS surface reflectances are provided at seven wavelengths - namely, $0.47,0.56,0.65,0.86,1.24,1.64$ and 
$2.13 \mu \mathrm{m}$. To get the surface reflectance outside this band, combination of sand, water and vegetation is taken such that it explains the MODIS observed surface reflectance. Another important input parameter is SSA, and monthly mean SSA over Gadanki observed using MISR is 0.923. A previous study reported monthly mean SSA over Gadanki during May to be about 0.92 as obtained from sky radiometer observations (Gadhavi and Jayaraman, 2010). Since local activity also may perturb the estimated forcings, NOAA interpolated outgoing long-wave radiation (OLR) are also used, along with CALIPSO observations, to make sure that there was no disturbance in and around the observational site on all the days of interest.

Average aerosol radiative forcings of all dusty days are found to be $-3,-23$ and $20 \mathrm{~W} \mathrm{~m}^{-2}$ at TOA, surface and within the atmosphere, respectively, over Gadanki, whereas they are $-2,-13$ and $11 \mathrm{~W} \mathrm{~m}^{-2}$, respectively, during nondusty cloud-free days, which are considered as normal days. Gadhavi and Jayaraman (2010), using ground-based measurement of AOD as an input, estimated radiative forcing for the month of May over Gadanki to be $-4,-24$ and $20 \mathrm{~W} \mathrm{~m}^{-2}$ at TOA, surface and within the atmosphere, respectively. Results from the present study closely match with these earlier results, though the inputs are from satellite measurements providing confidence in the current study. It is worth mentioning here that the previous study by Gadhavi and Jayaraman (2010) mainly focused on the effect of biomass burning on aerosol properties and reported a decrease in the contribution of soot particles during May and June, and increasing contribution of coarse mode particles, which may be inferred, based on the present study, as dust particles. Pandithurai et al. (2008) reported an increase of aerosol radiative forcing of about $80 \%$ (from 60 to $\left.111 \mathrm{~W} \mathrm{~m}^{-2}\right)$ within the atmosphere over Delhi $\left(28.63^{\circ} \mathrm{N}\right.$, $77.17^{\circ} \mathrm{E}$ ) due to transport of dust plume from the Thar Desert. In the present study over Gadanki also, we have found similar increase of atmospheric forcing of about $80 \%$ (from 11 to $20 \mathrm{~W} \mathrm{~m}^{-2}$ ) due to LTD. This result helps to conclude that the dust transported from the Thar Desert causes similar perturbation in the radiation budget over urban regions like Delhi as well as remote tropical regions like Gadanki in India.

Profiles of aerosol radiative forcing and heating rate during three typical dusty days over Gadanki are shown in Fig. 4. Aerosol radiative forcing and heating rate on a normal day, 25 May 2007 (a non-dusty day), is also plotted for reference. It can be seen that there is a redistribution of the vertical distribution of aerosol radiative forcing due to the presence of LTD in between 2 to $6 \mathrm{~km}$. And it is highly dependent on the vertical distribution of aerosols and its type. On 14 May 2007, LTD is present at $2.5 \mathrm{~km}$. As a result, LTD causes a $60 \%$ increase in atmospheric forcing and an about 60 times increase in heating rate within the dust layer. Similar increases are also observed on 16, 18 May and other dusty days, listed in Table 2.

\subsection{Dust-induced heating}

The dust optical depth $\left(\tau_{\text {dust }}\right)$ at $0.550 \mu \mathrm{m}$ is estimated as follows:

$\tau_{\text {dust }}=\frac{\int_{z_{1}}^{z_{2}} \sigma_{\mathrm{C}}(z) d z}{\int_{0}^{z_{2}} \sigma_{\mathrm{C}}(z) d z} \times \tau_{\mathrm{M}}$,

where $z_{1}$ and $z_{2}$ are the lower and upper altitude of the dust layer, respectively (as shown in Fig. 4), $\sigma_{\mathrm{C}}(z)$ is the vertical profile of the extinction coefficient obtained from CALIPSO observations, and $\tau_{\mathrm{M}}$ is the total columnar AOD over Gadanki obtained from MODIS. MODIS-AOD is considered as it represents a relatively bigger region of about $110 \mathrm{~km} \times 110 \mathrm{~km}$. The extinction coefficient is considered over a region of \pm 0.5 degree centered at the nearest point of Gadanki on the CALIPSO overpass trajectories. Note that CALIPSO measures extinction coefficient at $0.532 \mu \mathrm{m}$, whereas MODIS provides AOD at $0.550 \mu \mathrm{m}$. The uncertainty due to this wavelength mismatch is less than $2 \%$.

Radiative forcing and heating rate due to the dust layer are also calculated from the difference of mean values within the altitudes (where the dust layer is present) during dusty days and non-dusty days. The diurnal mean dust forcing and heating rates are given in Table 2 . The mean dust radiative forcing and heating rate are found to be $11.5 \pm 3.3 \mathrm{~W} \mathrm{~m}^{-2}$ and $0.60 \pm 0.26 \mathrm{~K} \mathrm{day}^{-1}$, respectively. Forcing and heating rate depend not only on the amount of dust but also on the height of the LTD. For example, on 14 May, LTD is present at $2.5 \mathrm{~km}$ with an optical depth of 0.16 exhibiting radiative forcing of $10 \mathrm{~W} \mathrm{~m}^{-2}$; on 16 May the LTD height increased to $2.8 \mathrm{~km}$ with reduced optical depth of 0.14 showing radiative forcing $11 \mathrm{~W} \mathrm{~m}^{-2}$; on 18 May, the LTD height further increased to $3 \mathrm{~km}$ and optical depth further reduced to 0.12 , exhibiting radiative forcing of $8 \mathrm{~W} \mathrm{~m}^{-2}$. A scatter plot of dust radiative forcing and heating rate are shown in Fig. 6, as functions of dust optical depth, estimated independently, and the best fitted surfaces are also shown. The vertical bars represent the perpendicular distances of points from the fitted surface. The dust forcing and heating rate efficiencies are found to be $43 \mathrm{~W} \mathrm{~m}^{-2}$ and $4 \mathrm{~K} \mathrm{day}^{-1}$ per optical depth, with a correlation coefficient of 0.93 and 0.88 , although the number of events considered here are relatively few (10 cases).

Average atmospheric forcing for the LTD during May 2007 is found to be $12 \mathrm{~W} \mathrm{~m}^{-2}$ (Table 2), while total atmospheric forcing is found to be $20 \mathrm{~W} \mathrm{~m}^{-2}$, similar to that observed by Gadhavi and Jayaraman (2010). Therefore, it can be concluded that LTD contributes to about $60 \%$ of the total atmospheric forcing during dusty days. The average heating rate due to LTD is about $0.60 \pm 0.26 \mathrm{~K} \mathrm{day}^{-1}$. A recent long-term study also showed a pronounced tropospheric warming rate of about $0.21^{\circ} \mathrm{C}$ per decade over the Himalayan region, particularly in the western Himalayas $\left(0.26^{\circ} \mathrm{C} /\right.$ decade $)$, possibly amplified due to elevated aerosolinduced solar absorption (Gautam et al., 2009, 2010). Using unmanned aircraft measurements over the northern Indian 

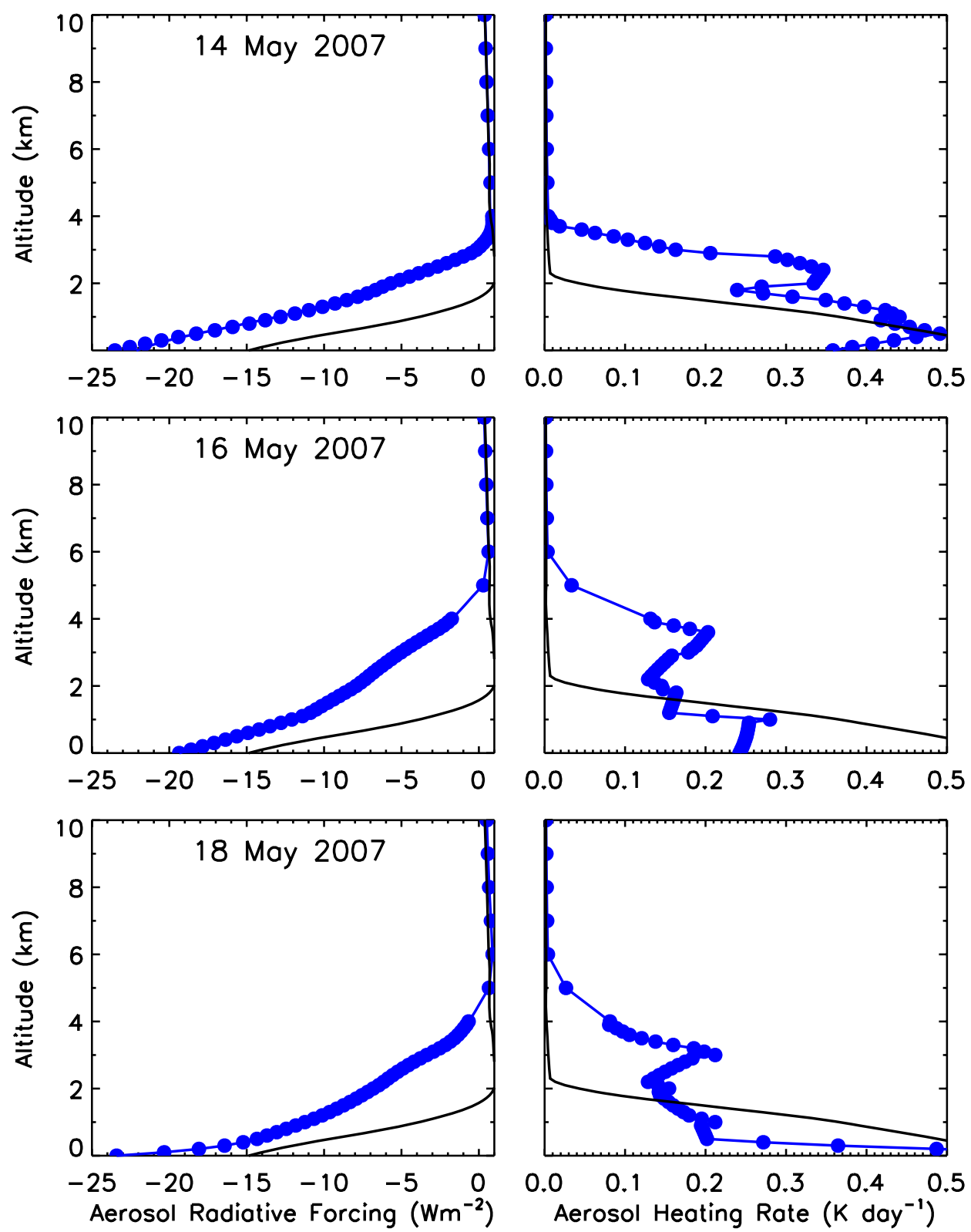

Fig. 5. Profiles of aerosol radiative forcing and heating rate within the lower atmosphere with a resolution of $100 \mathrm{~m}$. The solid black line represents the same on a non-dusty cloud-free day (25 May 2007).

Ocean, Ramanathan et al. (2007) reported aerosol heating rate of about $0.5-0.8 \mathrm{~K} \mathrm{day}^{-1}$ between 2 and $5 \mathrm{~km}$, which may contribute towards the weakening of the hydrological cycle, thereby reducing summer monsoon rainfall over India (Ramanathan et al., 2001). The present study also demonstrates a similar kind of heating in between 2 and $6 \mathrm{~km}$ over the study region due to the transported dust coming from the Thar Desert during May, which is the month before arrival of the Indian southwest monsoon, and such a high aerosol heating over southern India can provide information regarding the reduction of initial rainfall during southwest monsoon, and may help for better prediction of the Indian monsoon.

\subsection{Radiative effects of the dust layer depending on the aerosols below}

The near surface aerosols also can influence the radiative effects of LTD. Depending upon the type and the amount of aerosol loading below LTD, the dust radiative forcing and the heating rate can change significantly. To investigate these changes, a simulation study has been performed considering eight different environments below the LTD as follows. They are (1) no aerosols but the dust layer $\left(A_{0}\right)$, (2) half of the ambient aerosol loading $\left(A_{0.5}\right)$, (3) 1.5 times aerosol loading $\left(A_{1.5}\right)$ and equivalent (4) accumulation mode sea salt (SS), 


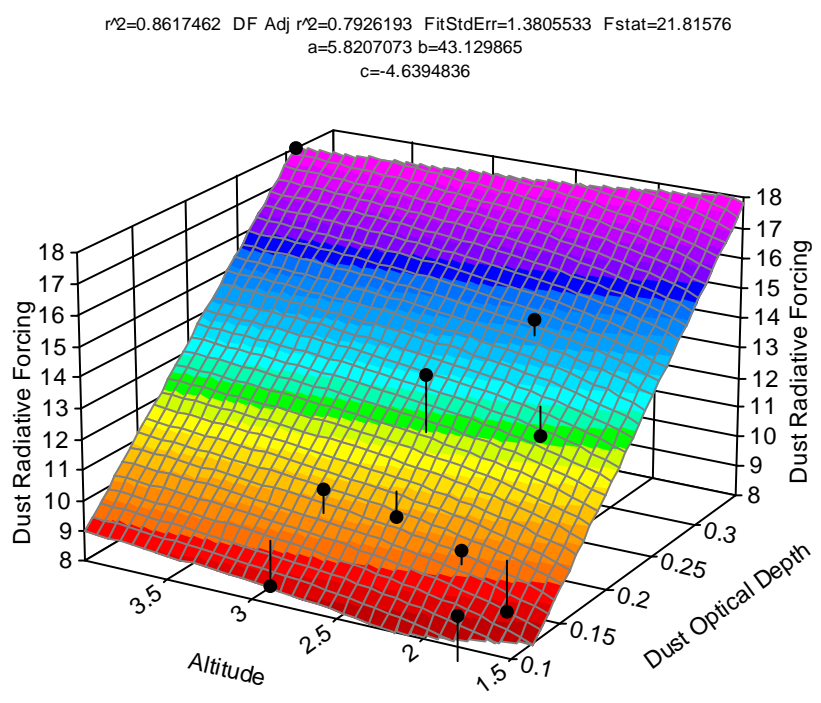

$\mathrm{r}^{\wedge} 2=0.78221839$ DF Adj $\mathrm{r} 2=0.67332759$ FitStdErr $=0.13662721 \quad$ Fstat $=12.571146$ $a=-0.14287102 b=3.6535272$ $c-0.21491018$

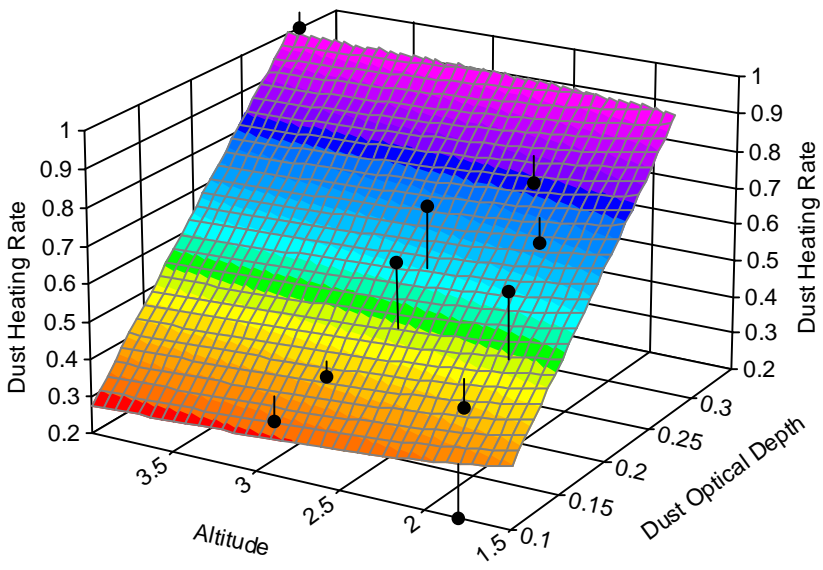

Fig. 6. Scattered plots of dust radiative forcing and heating rate as functions of altitude and optical depth of the dust layer over Gadanki. Best fitted surfaces with equation $z=a+b x+c / y$ are also plotted, where $a, b, c$ are the coefficients. The vertical bars represent the perpendicular distances from the surface. The dust layer radiative forcing and heating rate efficiency are found to be $43 \mathrm{~W} \mathrm{~m}^{-2}$ and $4 \mathrm{~K} \mathrm{day}^{-1}$ per unit optical depth of the dust layer with correlation coefficients $(R) 0.92$ and 0.88 , respectively.

(5) soot (SO), (6) urban (UR), (7) marine polluted (MP) and, (8) marine clean (MC) aerosols below LTD. The optical and physical properties of SS, SO, UR, MP, MC are obtained from the Optical Properties of Aerosols and Clouds (OPAC) model (Hess et al., 1998). It is important to note that SS is assumed to consist of purely scattering aerosols $(\mathrm{SSA}=1.0)$ and $\mathrm{SO}$ consist of purely absorbing aerosols with SSA $=0.2$,

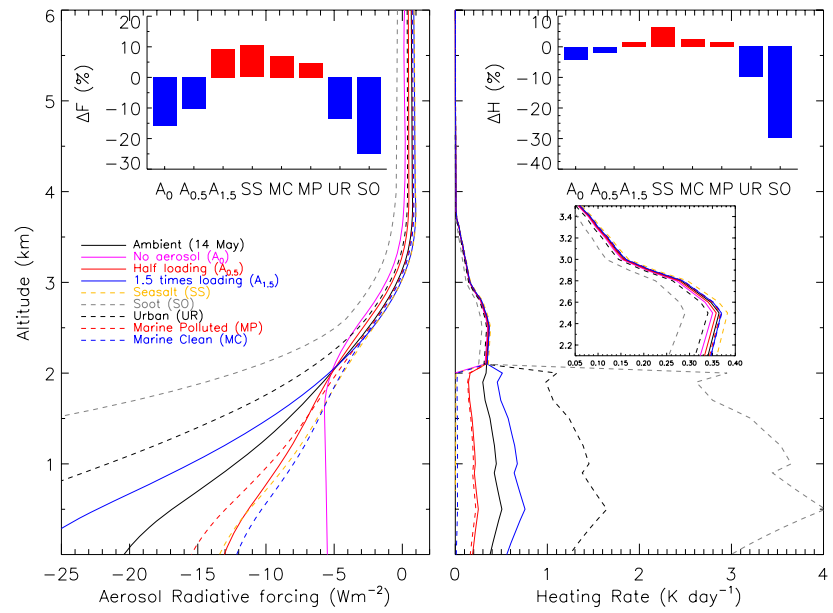

Fig. 7. Results of simulation study by considering different aerosol environments below the dust layer. They are (1) no aerosols $\left(A_{0}\right)$, (2) half aerosol loading $\left(A_{0.5}\right)$, (3) 1.5 times aerosol loading $\left(A_{1.5}\right)$, and equivalent (4) accumulation mode seasalt (SS), (5) soot (SO), (6) urban (UR), (7) marine polluted (MP), and (8) marine clean (MC) aerosols below the dust layer. The vertical bars represent the differences of radiative forcing $(\Delta F)$ and heating rate $(\Delta H)$ of the dust layer from the ambient condition (14 May 2007). The blue and red bars indicate the negative forcing or cooling effect and positive forcing or warming effect, respectively. See text for more details.

MC contains mostly water soluble aerosols like sulphate, nitrate, and sea salt aerosols with SSA $=0.996$, while MP has additional soot loading $\left(3.10 \mu \mathrm{g} \mathrm{m}^{-3}\right)$ with SSA $=0.963$, and UR has significantly higher soot loading $\left(7.78 \mu \mathrm{g} \mathrm{m}^{-3}\right)$ and contains no sea salt with SSA $=0.754$. Cases $1-3$ are chosen to investigate the changes in the radiative effects of the LTD due to changes in concentration of aerosol loading below the dust layer, and cases $4-8$ are chosen to investigate the changes in the LTD radiative effects due to changes in aerosol type.

The vertical distribution of radiative forcing and heating rate are estimated for the eight cases and shown in Fig. 7. The black line represents the radiative forcing and heating rate for the ambient dusty conditions, which in the present study are considered to be the conditions that were prevailing on 14 May 2007, a typical dusty day when the LTD was present in between $2-4 \mathrm{~km}$. The ambient surface forcing is $-20 \mathrm{~W} \mathrm{~m}^{-2}$ and the forcing gradually increases with altitude up to $4 \mathrm{~km}$ and later becomes constant $\left(0.5 \mathrm{~W} \mathrm{~m}^{-2}\right)$. When no aerosols are present below LTD $\left(A_{0}\right)$, surface forcing is minimum of about $-5.5 \mathrm{~W} \mathrm{~m}^{-2}$ and the atmospheric forcing is constant up to $2 \mathrm{~km}$ from the surface, whereas above $2 \mathrm{~km}$, i.e., in the LTD, forcing becomes lower than the ambient forcing. When the aerosol concentrations are reduced by $50 \%\left(A_{0.5}\right)$ and increased by $50 \%\left(A_{1.5}\right)$, the surface forcing and the forcing below LTD change accordingly. The surface forcings are -13 and $-27 \mathrm{~W} \mathrm{~m}^{-2}$ for $A_{0.5}$ and $A_{1.5}$, respectively, and increase gradually up to $2 \mathrm{~km}$. Above $2 \mathrm{~km}$ 
the situation reverses and the forcing is lower for $A_{0.5}$ and higher for $A_{1.5}$. This result shows that there is significant perturbation of forcing within the LTD for different amounts of aerosol loading below the dust layer. The heating rate also exhibits significant changes in response to different aerosol concentrations. Below $2 \mathrm{~km}$ the heating rates are proportional to the aerosol loading. For $A_{0}$, the heating rate is zero, and for $A_{0.5}$ and $A_{1.5}$ the heating rates are lower and higher than the ambient heating rates, respectively. Within the LTD, i.e., above $2 \mathrm{~km}$, the heating rates are significant in all three cases and less than ambient for $A_{0}$ and $A_{0.5}$, the former being the least, and higher than ambient for $A_{1.5}$. This is due to increased (decreased) upward-scattered radiation received by the LTD when the aerosol loading increases (decreases) below. The dust radiative forcing becomes more positive (negative), thereby increasing (decreasing) the warming effect within the dust layer.

Significant differences are also observed in the forcings when the type of aerosol changes below LTD. Minimum surface forcing of $-75 \mathrm{~W} \mathrm{~m}^{-2}$ is observed for SO followed by $-37,-15,-13$ and $-12 \mathrm{~W} \mathrm{~m}^{-2}$ for UR, MP, SS, and MC, respectively. The vertical distribution of radiative forcing and heating rate are similar to the ambient condition; however, their magnitudes vary. Within the dust layer, forcing is higher than the ambient for SS, followed by MC and MP, and forcing is less than the ambient for UR and SO in the same order. Similarly, the heating rate for the dust layer is also found to be the greatest for SS, followed by MC, MP, UR and SO, as shown within the inset in Fig. 7.

The bar plots present the perturbations of dust radiative forcing $(\Delta F)$ and dust heating rates $(\Delta H)$ in percentages relative to the ambient conditions, with blue bars representing negative forcings (cooling effects) and red bars representing positive forcings (warming effects). In case $A_{0}$ the radiation received by the dust layer below LTD is reflected solely by Earth's surface, resulting in negative forcing with cooling effect with respect to ambient. In case $A_{0.5}$ the dust layer receives additional scattered radiation due to the aerosols below reducing the negative forcing and cooling effect, and in case $A_{1.5}$ it receives more upward radiation, resulting in the positive forcing and warming effect. However, this upward radiation also depends on the type of aerosols below the dust layer. The negative forcing and cooling effect are maximum for SO, while positive forcing and warming effect are maximum for SS because the upward radiation received by the dust layer is minimum for $\mathrm{SO}$ and maximum for SS. In case SO, maximum negative forcing and cooling effect are due to maximum absorption of the downward solar radiation reaching Earth's surface and the upward reflected radiation from the surface, resulting in minimum upward radiation received by the dust layer. As soot loading decreases in cases UR, MP, MC and SS (where SSA are 0.754, $0.963,0.996$, and 1.0 , respectively), with increase in the scattering properties of the aerosols below LTD, the dust layer exhibits increased positive forcings and warming effects be- cause the dust layer receives relatively more upward radiation. Therefore, the warming effect decreases by about $25 \%$ with absorbing aerosols present in the boundary layer, and increases by about $15 \%$ for purely scattering marine boundary aerosols. Thus, the radiative forcing and heating rate of LTD are significantly influenced by boundary aerosol type and mass loading. Note that in Fig. 6 the heating in LTD reduces as the height of LTD increases. The reason could be due to more mass loading of absorbing aerosols within the boundary layer as analyzed above. It should also be noted that the LTD is determined from the higher depolarization ratio. However, it is possible that some dust aerosols are detrained into the boundary layer below LTD, but the high loading of spherical pollutants there significantly reduces the depolarization ratio. So the below-LTD absorption could come from either the detrained dust or the absorbing pollutants in the boundary layer.

The cases MC, MP and UR are chosen to make the present study more realistic. The Indian Ocean, BoB and Chennai $\left(13.04^{\circ} \mathrm{N}, 80.17^{\circ} \mathrm{E}\right)$ in the Indian subcontinent are very similar to MC, MP and UR, respectively, as reported by earlier researchers during INDOEX experiments (Jayaraman et al., 1998; Ramanathan et al., 2001; Satheesh, 2002; Satheesh et al., 2002). UR exhibits a cooling effect, while MC and MP exhibit warming effects in the same order. Heating of LTD increases by about $12 \%$ for MC, and decreases by about $7 \%$ for UR. Thus, the present simulation study suggests that the clean marine boundary layer such as the Indian Ocean increases the dust warming effects significantly compared to that for the absorbing urban aerosols over the mainland of India. It should to be noted that significant heating effect also occurs due to change of surface reflectivity as the underlying surface becomes dark over the marine region. However, in the present study, marine boundary layer aerosols are introduced only for comparison with the same underlying land surface. The present simulation study shows that marine boundary layer aerosols also increase the warming effects of LTD. In this scenario it can be said that heating in the dust layer can stabilize the lower troposphere over the Indian Ocean, while this effect is weakened for the dust layer over urban regions like Chennai. Stabilizing the marine atmosphere by this optically thick dust layer can weaken the local convection over the Indian Ocean, which could reduce cloud precipitation and in turn affect the Indian monsoonal circulation.

\section{Conclusions}

Using simultaneous observations of AOD, Ångstrom exponent, AI and SSA, along with vertical distribution of extinction coefficient and depolarization ratio obtained from spaceborne sensors, MODIS-Aqua, OMI-Aura, MISR-Terra and CALIOP-CALIPSO, dust layer radiative forcing and heating 
rates over Indian tropical region are characterized. The main findings are summarized below:

1. Dust transported from the Thar Desert produces an optically thick dust layer of $0.18 \pm 0.09$ optical thickness in between 2 and $6 \mathrm{~km}$ over southern India during May, just before the arrival of monsoon. Some of the dust layers exhibit signatures of fine layers of pollutants.

2. Use of high-resolution profiles of temperature and RH from GPS radiosonde measurements over Gadanki made it possible to calculate aerosol radiative forcing and heating rate in the lower atmosphere at a vertical resolution of $100 \mathrm{~m}$.

3. Presence of the dust layer redistributes the aerosol radiative forcing vertically and increases about $60 \%$ of the radiative forcing and heating rate by 60 times at that altitude with respect to non-dusty cloud-free days.

4. The radiative forcing and heating rate produced by the transported dust layer over Gadanki are $11.5 \pm$ $3.3 \mathrm{~W} \mathrm{~m}^{-2}$ and $0.60 \pm 0.25 \mathrm{~K} \mathrm{day}^{-1}$, respectively.

5. The transported dust layer radiative forcing and heating rate efficiency are found to be $43 \mathrm{~W} \mathrm{~m}^{-2}$ and $4 \mathrm{~K} \mathrm{day}^{-1}$ per optical depth, with a correlation coefficient of 0.92 and 0.88 , respectively.

6. The simulation study shows that radiative forcing and heating rate of the dust layer strongly depend on the boundary layer aerosol type and mass loading. An increase of $25 \%$ heating by the dust layer is found over relatively cleaner regions (Gadanki) than urban regions in tropical India, and a further $15 \%$ of heating increases over the marine region.

This shows the significant warming in the free troposphere due to the presence of the dust layer over the tropical Indian region. Based on these results, it can be said that such a layer of transported dust over marine region may produce relatively more stable atmosphere than over land, which can spin down the hydrological cycle and can cause significant perturbation in the Indian monsoon circulation. It is important to note that these conclusions are drawn by considering a few best cases. More in-depth analysis by considering a large database, from both satellite and in situ observations, will help in resolving further issues and enable a better understanding.

Acknowledgements. We acknowledge the MODIS, OMI, MISR and CALIPSO mission scientists and associated NASA personnel for the production of the data used in this research effort. We also thank the NOAA Air Resources Laboratory for the HYSPLIT model (http://www.arl.noaa.gov/ready.html) and OLR data. Special thanks to the British Atmospheric Data Centre, which is part of the
NERC National Centre for Atmospheric Science (NCAS), for providing access to use data from the European Centre for MediumRange Weather Forecasts. SKD \& JPC are supported by NSC of Taiwan through grant 100-2119-M-002 -023 -MY5.

Topical Editor P. Drobinski thanks C. Flamant and one anonymous referee for their help in evaluating this paper.

\section{References}

Ackerman, A. S., Toon, O. B., Stevens, D. E., Heymsfield, A. J., Ramanathan, V., and Welton, E. J.: Reduction of Tropical Cloudiness by Soot, Science, 288, 1042-1047, 2000.

Badarinath, K. V., Kharol, S. K., Kaskaoutis, D. G., and Kambezidis, H. D.: Case study of a dust storm over Hyderabad area, India: its impact on solar radiation using satellite data and ground measurements, Sci. Total Environ., 384, 316-32, 2007.

Badarinath, K. V. S., Kumar Kharol, S., Krishna Prasad, V., Rani Sharma, A., Reddi, E. U. B., Kambezidis, H. D., and Kaskaoutis, D. G.: Influence of natural and anthropogenic activities on UV Index variations - a study over tropical urban region using ground based observations and satellite data, J. Atmos. Chem., 59, 219-236, 2008.

Badarinath, K. V. S., Kharol, S. K., Kaskaoutis, D. G., Sharma, A. R., Ramaswamy, V., and Kambezidis, H. D.: Long-range transport of dust aerosols over the Arabian Sea and Indian region - A case study using satellite data and ground-based measurements, Global Planet. Change, 72, 164-181, 2010.

Bates, T. S., Anderson, T. L., Baynard, T., Bond, T., Boucher, O., Carmichael, G., Clarke, A., Erlick, C., Guo, H., Horowitz, L., Howell, S., Kulkarni, S., Maring, H., McComiskey, A., Middlebrook, A., Noone, K., O’Dowd, C. D., Ogren, J., Penner, J., Quinn, P. K., Ravishankara, A. R., Savoie, D. L., Schwartz, S. E., Shinozuka, Y., Tang, Y., Weber, R. J., and Wu, Y.: Aerosol direct radiative effects over the northwest Atlantic, northwest Pacific, and North Indian Oceans: estimates based on in-situ chemical and optical measurements and chemical transport modeling, Atmos. Chem. Phys., 6, 1657-1732, doi:10.5194/acp-6-1657-2006, 2006.

Bellouin, N., Boucher, O., Haywood, J., and Reddy, M. S.: Global estimate of aerosol direct radiative forcing from satellite measurements, Nature, 438, 1139-1141, 2005.

Boucher, O. and Tanré, D.: Estimation of the aerosol perturbation to the Earth's Radiative Budget over oceans using POLDER satellite aerosol retrievals, Geophys. Res. Lett., 27, 1103-1106, 2000.

Chandra, S., Satheesh, S., and Srinivasan, J.: Can the state of mixing of black carbon aerosols explain the mystery of "excess" atmospheric absorption?, Geophys. Res. Lett., 31, L19109, doi:10.1029/2004GL020662, 2004.

Chen, W.-T., Kahn, R. A., Nelson, D., Yau, K., and Seinfeld, J. H.: Sensitivity of multiangle imaging to the optical and microphysical properties of biomass burning aerosols, J. Geophys. Res., 113, D10203, doi:10.1029/2007JD009414, 2008.

Chen, Y., Li, Q., Kahn, R. A., Randerson, J. T., and Diner, D. J.: Quantifying aerosol direct radiative effect with Multiangle Imaging Spectroradiometer observations: Top-of-atmosphere albedo change by aerosols based on land surface types, J. Geophys. Res., 114, D02109, doi:10.1029/2008JD010754, 2009.

Chou, M.-D., Chan, P.-K., and Wang, M.: Aerosol Radiative Forcing Derived from SeaWiFS-Retrieved Aerosol Optical Proper- 
ties, J. Atmos. Sci., 59, 748-757, 2002.

Christopher, S. A. and Zhang, J.: Cloud-free shortwave aerosol radiative effect over oceans: Strategies for identifying anthropogenic forcing from Terra satellite measurements, Geophys. Res. Lett., 31, L18101, doi:10.1029/2004GL020510, 2004.

Das, S. K., Taori, A., and Jayaraman, A.: On the role of dust storms in triggering atmospheric gravity waves observed in the middle atmosphere, Ann. Geophys., 29, 1647-1654, doi:10.5194/angeo29-1647-2011, 2011.

de Villiers, R. A., Ancellet, G., Pelon, J., Quennehen, B., Schwarzenboeck, A., Gayet, J. F., and Law, K. S.: Airborne measurements of aerosol optical properties related to early spring transport of mid-latitude sources into the Arctic, Atmos. Chem. Phys., 10, 5011-5030, doi:10.5194/acp-10-5011-2010, 2010.

Dey, S., Tripathi, S. N., and Singh, R. P.: Influence of dust storms on the aerosol optical properties over the Indo-Gangetic basin, J. Geophys. Res., 109, D20211, doi:10.1029/2004JD004924, 2004.

Diner, D. J., Abdou, W. A., Ackerman, T. P., Crean, K., Gordon, H. R., Kahn, R. A., and Martonchik, J. V.: A. MISR level 2 aerosol retrieval algorithm theoretical basis JPL D-11400, Revision G, Jet Propul. Lab.,Pasadena, Calif., 2008.

Draxler, R. R. and Hess, G. D.: An overview of the HYSPLIT modelling system for trajectories, dispersion, and deposition, Australian Meteorological Magazine, 47, 295-308, 1998.

Eck, T. F., Holben, B. N., Dubovik, O., Smirnov, A., Slutsker, I., Lobert, J. M., and Ramanathan, V.: Column-integrated aerosol optical properties over the Maldives during the northeast monsoon for 1998-2000, J. Geophys. Res., 106, 28555-28566, 2001.

Gadhavi, H. and Jayaraman, A.: Absorbing aerosols: contribution of biomass burning and implications for radiative forcing, Ann. Geophys., 28, 103-111, doi:10.5194/angeo-28-103-2010, 2010.

Gautam, R., Hsu, N. C., Lau, K. M., Tsay, S. C., and Kafatos, M.: Enhanced pre-monsoon warming over the Himalayan-Gangetic region from 1979 to 2007, Geophys. Res. Lett., 36, L07704, doi:10.1029/2008GL036967, 2009.

Gautam, R., Hsu, N. C., and Lau, K. M.: Premonsoon aerosol characterization and radiative effects over the Indo-Gangetic Plains: Implications for regional climate warming, J. Geophys. Res., 115, D17208, doi:10.1029/2010JD013819, 2010.

Gautam, R., Hsu, N. C., Tsay, S. C., Lau, K. M., Holben, B., Bell, S., Smirnov, A., Li, C., Hansell, R., Ji, Q., Payra, S., Aryal, D., Kayastha, R., and Kim, K. M.: Accumulation of aerosols over the Indo-Gangetic plains and southern slopes of the Himalayas: distribution, properties and radiative effects during the 2009 pre-monsoon season, Atmos. Chem. Phys., 11, 1284112863, doi:10.5194/acp-11-12841-2011, 2011.

Generoso, S., Bey, I., Labonne, M., and Bréon, F.-M.: Aerosol vertical distribution in dust outflow over the Atlantic: Comparisons between GEOS-Chem and Cloud-Aerosol Lidar and Infrared Pathfinder Satellite Observation (CALIPSO), J. Geophys. Res., 113, D24209, doi:10.1029/2008JD010154, 2008.

Gobbi, G. P., Barnaba, F., and Ammannato, L.: The vertical distribution of aerosols, Saharan dust and cirrus clouds in Rome (Italy) in the year 2001, Atmos. Chem. Phys., 4, 351-359, doi:10.5194/acp-4-351-2004, 2004.

Guan, H., Esswein, R., Lopez, J., Bergstrom, R., Warnock, A., Follette-Cook, M., Fromm, M., and Iraci, L. T.: A multidecadal history of biomass burning plume heights identified using aerosol index measurements, Atmos. Chem. Phys., 10, 6461-
6469, doi:10.5194/acp-10-6461-2010, 2010.

Haywood, J. M.: Tropospheric Aerosol Climate Forcing in ClearSky Satellite Observations over the Oceans, Science, 283, 1299 1303, 1999.

Haywood, J., Francis, P., Osborne, S., Glew, M., Loeb, N., Highwood, E., Tanré, D., Myhre, G., Formenti, P., and Hirst, E.: Radiative properties and direct radiative effect of Saharan dust measured by the C-130 aircraft during SHADE: 1 . Solar spectrum, J. Geophys. Res., 108, 8577, doi:10.1029/2002JD002687, 2003.

Hess, M., Koepke, P., and Schult, I.: Optical Properties of Aerosols and Clouds: The Software Package OPAC, B. Am. Meteorol. Soc., 79, 831-844, 1998.

Hsu, N. C., Si-Chee, T., King, M. D., and Herman, J. R.: Aerosol properties over bright-reflecting source regions, IEEE Geosci. Remote Sens., 42, 557-569, 2004.

Hu, Y., Vaughan, M., Liu, Z., Lin, B., Yang, P., Flittner, D., Hunt, B., Kuehn, R., Huang, J., Wu, D., Rodier, S., Powell, K., Trepte, C., and Winker, D.: The depolarization - attenuated backscatter relation: CALIPSO lidar measurements vs. theory, Opt. Express, 15, 5327-5332, 2007.

Hu, Y., Winker, D., Vaughan, M., Lin, B., Omar, A., Trepte, C., Flittner, D., Yang, P., Nasiri, S. L., Baum, B., Holz, R., Sun, W., Liu, Z., Wang, Z., Young, S., Stamnes, K., Huang, J., and Kuehn, R.: CALIPSO/CALIOP Cloud Phase Discrimination Algorithm, J. Atmos. Ocean. Technol., 26, 2293-2309, 2009.

Jayaraman, A., Lubin, D., Ramachandran, S., Ramanathan, V., Woodbridge, E., Collins, W. D., and Zalpuri, K. S.: Direct observations of aerosol radiative forcing over the tropical Indian Ocean during the January-February 1996 pre-INDOEX cruise, J. Geophys. Res., 103, 13827-13836, 1998.

Kahn, R. A., Gaitley, B. J., Garay, M. J., Diner, D. J., Eck, T. F., Smirnov, A., and Holben, B. N.: Multiangle Imaging SpectroRadiometer global aerosol product assessment by comparison with the Aerosol Robotic Network, J. Geophys. Res., 115, D23209, doi:10.1029/2010JD014601, 2010.

Kalashnikova, O. V. and Kahn, R.: Ability of multiangle remote sensing observations to identify and distinguish mineral dust types: 2. Sensitivity over dark water, J. Geophys. Res., 111, D11207, doi:10.1029/2005JD006756, 2006.

Kaskaoutis, D. G., Kambezidis, H. D., Nastos, P. T., and Kosmopoulos, P. G.: Study on an intense dust storm over Greece, Atmos. Environ., 42, 6884-6896, 2008.

Kaufman, Y. J., Tanré, D., Remer, L. A., Vermote, E. F., Chu, A., and Holben, B. N.: Operational remote sensing of tropospheric aerosol over land from EOS moderate resolution imaging spectroradiometer, J. Geophys. Res., 102, 17051-17067, 1997.

Kaufman, Y. J., Tanré, D., Dubovik, O., Karnieli, A., and Remer, L. A.: Absorption of sunlight by dust as inferred from satellite and ground-based remote sensing, Geophys. Res. Lett., 28, 1479-1482, 2001.

Kharol, S. K. and Badarinath, K. V. S.: Impact of biomass burning on aerosol properties over tropical urban region of Hyderabad, India, Geophys. Res. Lett., 33, L20801, doi:10.1029/2006GL026759, 2006.

Kosmopoulos, P. G., Kaskaoutis, D. G., Nastos, P. T., and Kambezidis, H. D.: Seasonal variation of columnar aerosol optical properties over Athens, Greece, based on MODIS data, Remote Sens. Environ., 112, 2354-2366, 2008. 
Krishnan, R. and Ramanathan, V.: Evidence of surface cooling from absorbing aerosols, Geophys. Res. Lett., 29, 1340, doi:10.1029/2002GL014687, 2002.

Lemaître, C., Flamant, C., Cuesta, J., Raut, J.-C., Chazette, P., Formenti, P., and Pelon, J.: Radiative forcing associated with a springtime case of Bodélé and Sudan dust transport over West Africa, Atmos. Chem. Phys. Discuss., 10, 8811-8858, doi:10.5194/acpd-10-8811-2010, 2010.

Levy, R. C., Remer, L. A., and Dubovik, O.: Global aerosol optical properties and application to Moderate Resolution Imaging Spectroradiometer aerosol retrieval over land, J. Geophys. Res., 112, D13210, doi:10.1029/2006JD007815, 2007.

Martonchik, J. V., Diner, D. J., Crean, K. A., and Bull, M. A.: Regional aerosol retrieval results from MISR, IEEE Geosci. Remote Sens., 40, 1520-1531, 2002.

Mishra, S. K. and Tripathi, S. N.: Modeling optical properties of mineral dust over the Indian Desert, J. Geophys. Res., 113, D23201, doi:10.1029/2008JD010048, 2008.

Murayama, T., Okamoto, H., Kaneyasu, N., Kamataki, H., and Miura, K.: Application of lidar depolarization measurement in the atmospheric boundary layer: Effects of dust and sea-salt particles, J. Geophys. Res., 104, 31781-31792, 1999.

Murayama, T., Sugimoto, N., Uno, I., Kinoshita, K., Aoki, K., Hagiwara, N., Liu, Z., Matsui, I., Sakai, T., Shibata, T., Arao, K., Sohn, B.-J., Won, J.-G., Yoon, S.-C., Li, T., Zhou, J., Hu, H., Abo, M., Iokibe, K., Koga, R., and Iwasaka, Y.: Ground-based network observation of Asian dust events of April 1998 in east Asia, J. Geophys. Res., 106, 18345-18359, 2001.

Nath, D., Venkat Ratnam, M., Jagannadha Rao, V. V. M., Krishna Murthy, B. V., and Vijaya Bhaskara Rao, S.: Gravity wave characteristics observed over a tropical station using highresolution GPS radiosonde soundings, J. Geophys. Res., 114, D06117, doi:10.1029/2008JD011056, 2009.

Nee, J. B., Chiang, C.-W., Hu, H.-1., Hu, S.-X., and Yu, J.-Y.: Lidar measurements of Asian dust storms and dust cloud interactions, J. Geophys. Res., 112, D15202, doi:10.1029/2007JD008476, 2007.

Niranjan, K., Anjana Devi, T., Spandana, B., Sreekanth, V., and Madhavan, B. L.: Evidence for control of black carbon and sulfate relative mass concentrations on composite aerosol radiative forcing: Case of a coastal urban area, J. Geophys. Res., 117, D05205, doi:10.1029/2011JD016752, 2012.

Omar, A. H., Winker, D. M., Vaughan, M. A., Hu, Y., Trepte, C. R., Ferrare, R. A., Lee, K.-P., Hostetler, C. A., Kittaka, C., Rogers, R. R., Kuehn, R. E., and Liu, Z.: The CALIPSO Automated Aerosol Classification and Lidar Ratio Selection Algorithm, J. Atmos. Ocean. Technol., 26, 1994-2014, 2009.

Pandithurai, G., Dipu, S., Dani, K. K., Tiwari, S., Bisht, D. S., Devara, P. C. S., and Pinker, R. T.: Aerosol radiative forcing during dust events over New Delhi, India, J. Geophys. Res., 113, D13209, doi:10.1029/2008JD009804, 2008.

Patadia, F., Gupta, P., Christopher, S. A., and Reid, J. S.: A Multisensor satellite-based assessment of biomass burning aerosol radiative impact over Amazonia, J. Geophys. Res., 113, D12214, doi:10.1029/2007JD009486, 2008.

Podgorny, I. A. and Ramanathan, V.: A modeling study of the direct effect of aerosols over the tropical Indian Ocean, J. Geophys. Res., 106, 24097-24105, 2001.
Ramanathan, V., Crutzen, P. J., Kiehl, J. T., and Rosenfeld, D.: Aerosols, climate, and the hydrological cycle, Science, 294, 2119-2124, 2001.

Ramanathan, V., Ramana, M. V., Roberts, G., Kim, D., Corrigan, C., Chung, C., and Winker, D.: Warming trends in Asia amplified by brown cloud solar absorption, Nature, 448, 575-578, 2007.

Remer, L. A., Tanré, D., Kaufman, Y. J., Ichoku, C., Mattoo, S., Levy, R., Chu, D. A., Holben, B., Dubovik, O., Smirnov, A., Martins, J. V., Li, R. R., and Ahmad, Z.: Validation of MODIS aerosol retrieval over ocean, Geophys. Res. Lett., 29, 1618, doi:10.1029/2001GL013204, 2002.

Remer, L. A., Kaufman, Y. J., Tanré, D., Mattoo, S., Chu, D. A., Martins, J. V., Li, R. R., Ichoku, C., Levy, R. C., Kleidman, R. G., Eck, T. F., Vermote, E., and Holben, B. N.: The MODIS Aerosol Algorithm, Products, and Validation, J. Atmos. Sci., 62, 947-973, 2005.

Ricchiazzi, P., Yang, S., Gautier, C., and Sowle, D.: SBDART: A Research and Teaching Software Tool for Plane-Parallel Radiative Transfer in the Earth's Atmosphere, B. Am. Meteorol. Soc., 79, 2101-2114, 1998.

Satheesh, S. K.: Radiative forcing by aerosols over Bay of Bengal region, Geophys. Res. Lett., 29, 2083, doi:10.1029/2002GL015334, 2002.

Satheesh, S. K., Ramanathan, V., Holben, B. N., Moorthy, K. K., Loeb, N. G., Maring, H., Prospero, J. M., and Savoie, D.: Chemical, microphysical, and radiative effects of Indian Ocean aerosols, J. Geophys. Res., 107, 4725, doi:10.1029/2002JD002463, 2002.

Solmon, F., Mallet, M., Elguindi, N., Giorgi, F., Zakey, A., and Konaré, A.: Dust aerosol impact on regional precipitation over western Africa, mechanisms and sensitivity to absorption properties, Geophys. Res. Lett., 35, L24705, doi:10.1029/2008GL035900, 2008.

Torres, O., Bhartia, P. K., Herman, J. R., Ahmad, Z., and Gleason, J.: Derivation of aerosol properties from satellite measurements of backscattered ultraviolet radiation: Theoretical basis, J. Geophys. Res., 103, 17099-17110, 1998.

Torres, O., Tanskanen, A., Veihelmann, B., Ahn, C., Braak, R., Bhartia, P. K., Veefkind, P., and Levelt, P.: Aerosols and surface UV products from Ozone Monitoring Instrument observations: An overview, J. Geophys. Res., 112, D24S47, doi:10.1029/2007JD008809, 2007.

Uchiyama, A., Yamazaki, A., Togawa, H., Asano, J., and Shi, G.: Single Scattering Albedo of Aeolian Dust as Inferred from Skyradiometer and in situ Ground-based Measurement, SOLA, 1, 209-212, 2005.

Vaughan, M. A., Winker, D. M., and Powell, K. A.: CALIOP Algorithm Theoretical Basis Document Part 2: Feature Detection and Layer Properties Algorithms, Rep.PC-SCI-202, 87 pp., NASA Langley Res. Cent., Hampton, VA, 2005.

Vaughan, M. A., Powell, K. A., Winker, D. M., Hostetler, C. A., Kuehn, R. E., Hunt, W. H., Getzewich, B. J., Young, S. A., Liu, Z., and McGill, M. J.: Fully Automated Detection of Cloud and Aerosol Layers in the CALIPSO Lidar Measurements, J. Atmos. Ocean. Technol., 26, 2034-2050, 2009.

Vernier, J. P., Pommereau, J. P., Garnier, A., Pelon, J., Larsen, N., Nielsen, J., Christensen, T., Cairo, F., Thomason, L. W., Leblanc, T., and McDermid, I. S.: Tropical stratospheric aerosol layer from CALIPSO lidar observations, J. Geophys. Res., 114, 
D00H10, doi:10.1029/2009JD011946, 2009.

Wang, C.-C., Lee, C.-T., Liu, S. C., and Chen, J.-P.: Aerosol Characterization at Taiwan's Northern Tip During Ace-Asia, TAO, 15, 839-855, 2004.

Yorks, J. E., McGill, M., Rodier, S., Vaughan, M., Hu, Y., and Hlavka, D.: Radiative effects of African dust and smoke observed from Clouds and the Earth's Radiant Energy System (CERES) and Cloud-Aerosol Lidar with Orthogonal Polarization (CALIOP) data, J. Geophys. Res., 114, D00H04, doi:10.1029/2009JD012000, 2009.
Yu, H., Dickinson, R. E., Chin, M., Kaufman, Y. J., Zhou, M., Zhou, L., Tian, Y., Dubovik, O., and Holben, B. N.: Direct radiative effect of aerosols as determined from a combination of MODIS retrievals and GOCART simulations, J. Geophys. Res., 109, D03206, doi:10.1029/2003JD003914, 2004. 